\title{
Pendapatan dan Persepsi Anggota terhadap Penerapan Internal Control System pada Pertanian Padi Organik
}

Revenue and Perception of Members of the Implementation of Internal Control System in Organic Rice Farming

\author{
Netra Mirawati ${ }^{* 1}$, Aris Munandar ${ }^{* 2}$, dan Sapta Raharja ${ }^{\sharp 3}$ \\ ${ }^{1}$ Departemen Pertanian \\ Jl. Harsono RM, Ragunan, Pasar Minggu, Jakarta Selatan 12550 \\ ${ }^{2}$ Departemen Arsitektur Lansekap, Fakultas Pertanian, Institut Pertanian Bogor \\ ${ }^{3}$ Departemen Teknologi Industri Pertanian, Fakultas Teknologi Pertanian, Institut Pertanian Bogor \\ Jl. Kamper, Kampus IPB Darmaga, Bogor 16680
}

\begin{abstract}
ABSTRAK
Sistem Pengendalian Internal atau Internal Control System (ICS) adalah manajemen konsolidasi mengenai upaya untuk sertifikasi produk organik. Karena mekanisme kolektif, petani mampu mengelola agribisnis yang lebih menguntungkan secara finansial. Tujuan penelitian ini: (1) menganalisis perbedaan tingkat pendapatan kelompok tani (poktan) yang bersertifikat organik dan non-organik bersertifikat, (2) mendapatkan gambaran pelaksanaan ICS di poktan Gapoktan Simpatik, dan (3) menganalisis persepsi anggota kelompok terhadap pelaksanaan ICS, baik bersertifikat atau tidak bersertifikat organik. Penelitian ini merupakan studi kasus di daerah hulu sungai Cideres dan Cigunungjaga di Kabupaten Sukahening, Tasikmalaya, yang merupakan anggota dari Gapoktan Simpatik. Analisis dilakukan dengan menggunakan rasio Revenue/Cost (R/C), analisis homogenitas data dengan tingkat pendapatan menggunakan Kolmogorov-Smirnov, analisis perbedaan pendapatan antara kedua kelompok petani independen dengan menggunakan uji Mann-Whitney, dan analisis biplot untuk analisis persepsi anggota kelompok terhadap peubah implementasi ICS. Hasil penelitian menunjukkan bahwa rasio R/C untuk kelompok bersertifikat adalah 1,77, dan kelompok tidak bersertifikat 1,53. Tingkat pendapatan rataan dari kelompok bersertifikat Rp19.394.800/ha/tahun, sedangkan tidak bersertifikat Rp12.728.940/ha/tahun. Hasil penelitian juga menunjukkan bahwa persepsi terhadap pelaksanaan ICS kelompok bersertifikat lebih baik daripada tidak bersertifikat. Sebagian besar kelompok bersertifikat mendekati vektor dari semua peubah, yang berarti bahwa mereka puas dan akrab dengan semua variabel, sedangkan kelompok tidak bersertifikat tidak mendekati vektor. Parameter yang luas bervariasi dengan respon kelompok bersertifikat adalah peubah pembelian, penanganan, pengolahan, dan ekspor, sedangkan peubah respon yang paling seragam dari poktan adalah peubah personil organisasi dan ICS. Sementara kelompok yang tidak bersertifikat disediakan berbagai penilaian terhadap peubah manajemen risiko dan penilaian yang seragam pada pemeriksaan eksternal dan sertifikasi.
\end{abstract}

Kata kunci: pendapatan, persepsi, internal control system, pertanian padi organik

\section{ABSTRACT}

Internal Control System (ICS) is a consolidated management concerning the effort to certify organic products. Due to its collective mechanism, farmers are able to manage its agribusiness more profitably financially. The purpose of this study was (1) to analyze the differences in income levels of farmer groups who are certified organic and non-certified organic, (2) to get an overview of the implementation of ICS in farmers group Gapoktan Simpatik, and (3) to analyze the perceptions of group members towards the implementation of ICS either certified or non-certified organic. This research was on a case study at upper stream of Cideres and Cigunungjaga watershed in the district of Sukahening, Tasikmalaya, which is a member of Gapoktan Simpatik. The analysis was performed using the $\mathrm{R} / \mathrm{C}$ ratio,

\footnotetext{
*) Korespondensi:

Jl. Harsono RM, Ragunan, Pasar Minggu, Jakarta Selatan 12550 ; e-mail: netra_ghania@yahoo.com
} 
homogeneity analysis of data by income level using the Kolmogorov-Smirnov, analysis of income differences between the two groups of independent farmers using the Mann-Whitney test, and biplot analysis for the analysis of perceptions of group members toward ICS implementation variables. The results showed that the $\mathrm{R} / \mathrm{C}$ ratio for the certified group was 1.77 , and for non-certified group 1.53 . The average income level of certified group was Rp19,394,800/ha/year, while the non-certified Rp12,728,940/ ha/year. The results also showed that perception toward ICS implementation of certified group was better than the non-certified. Most of the certified group respondent approached the vector of all variables, which means that they were satisfied and familiar with all the variables, while the group of respondents who were non-certified did not approach the vector. The parameters that were widely varied by respondent group responses were the certified variable of purchase, handling, processing, and export, while the most uniform response variables of the respondents were variable of organizational and ICS personnel. While the groups that were not certified provided a variety of assessment on the variables of risk management and uniform assessment on external inspection and certification.

Key words: revenue, perception, internal control system, organic rice farming

\section{PENDAHULUAN}

Sejak berkembangnya pertanian organik di Indonesia, banyak kesimpangsiuaran tentang definisi dan persyaratan organik yang sesungguhnya. Pada tahun 2002, telah dirumuskan dan ditetapkan Standar Nasional Indonesia (SNI) untuk sistem pangan organik yang tujuannya agar terdapat kesepakatan tentang pemahaman organik yang sama terutama antara produsen dan konsumen. Standar ini pada tahun 2010 telah direvisi untuk menyesuaikan dengan berbagai perkembangan organik yang ada, baik di Indonesia maupun di dunia internasional.

Potensi pengembangan pertanian organik di Indonesia cukup terbuka luas karena kekayaan keanekaragaman hayatinya yang unik, limpahan sinar matahari, air dan tanah yang masih luas yang dapat dimanfaatkan bagi lahan organik. Menurut Aliansi Organik Indonesia atau AOI (2009), luas total pertanian organik di Indonesia pada tahun 2009 sudah mencapai 231.697,11 ha yang tersebar di Sulawesi, Jawa, Sumatera dan Kalimantan.

Berdasarkan data di atas, dapat dilihat bahwa jumlah lahan yang telah disertifikasi baru mencapai $42 \%$, sehingga tak heran bila banyak produk yang beredar adalah produk yang tanpa sertifikat organik. Sertifikasi beras organik di Indonesia dilakukan oleh Lembaga Sertifikasi Organik (LSO) yang telah diakreditasi oleh Komite Akreditasi Nasional (KAN) dengan mengacu kepada penerapan sistem jaminan mutu organik berdasarkan persyaratan yang tertuang dalam SNI 6729 : 2010 Sistem pangan organik. Lembaga sertifikasi nasional pada umumnya akan mengenakan biaya yang lebih rendah dibanding- kan dengan berbagai lembaga sertifikasi internasional, tetapi kurang dikenal di beberapa negara asing (Pascal, 2007).

International Federation of Organic Agriculture Movements (IFOAM) telah mengembangkan cara sertifikasi berkelompok melalui penerapan Internal Control System (ICS) untuk mengatasi persoalan biaya sertifikasi. Sistem ini dikembangkan untuk tujuan memperkuat gerakan pertanian organik di negara berkembang (Lechleitner dan Eisenlohr, 2004). Gabungan Kelompok Tani (Gapoktan) Simpatik yang berada di Kabupaten Tasikmalaya adalah Gapoktan yang telah menerapkan ICS yang berhasil disertifikasi oleh Institute for Market Ocologi (IMO). Persoalan utamanya, sertifikasi ICS pada Gapoktan ini dikuasai oleh traider, sehingga posisi tawar Gapoktan kurang kuat maka perlu dikaji apakah ada perubahan tingkat pendapatan antara yang telah mendapat sertifikat dan yang belum memiliki sertifikat.

Gapoktan Simpatik adalah gabungan dari 28 poktan dengan total jumlah 2.045 petani dan 288 wanita tani sehingga berjumlah 2.333 orang dengan luasan lahan 329,33 Ha. Pertanian organik dalam Gapoktan ini dimulai dari mengembangkan pertanian organik dengan System Rice of Intensification (SRI) dan terus meningkatkan pemahaman organik. Sejak tahun 2006, poktan tersebut bergabung membentuk Gapoktan Simpatik. Gapoktan ini dalam menerapkan ICS mempunyai struktur organisasi yang terdiri dari Unit ICS, Tim Teknis, Bagian Pemasaran dan Komisi Persetujuan.

Penerapan ICS pada Gapoktan ini dimulai sejak tahun 2008. Penerapan ICS ini melalui beberapa tahap mulai dari penyusunan dokumen, 
pelatihan dan pemahaman kepada semua anggota kelompok. Berdasarkan hasil penilaian IMO, dari 28 jumlah poktan yang tergabung dalam Gapoktan Simpatik, 11 kelompok tani (poktan) telah mendapat sertifikat organik, 3 poktan dalam tahap konversi, dan 14 poktan masih belum mendapat sertifikat, karena dinilai belum sesuai dengan persyaratan yang tertuang dalam dokumen ICS. Ketidakberhasilan semua anggota Gapoktan perlu dievaluasi, apakah ada perbedaan persepsi antara kelompok yang bersertifikat dengan kelompok yang tidak bersertifikat terhadap persyaratan yang tertuang dalam pedoman ICS. Hal ini penting sebagai evaluasi bagi Gapoktan selanjutnya untuk mensukseskan semua anggotanya mendapat sertifikat organik.

Berdasarkan uraian di atas maka tujuan penelitian ini: (1) Menganalisis perbedaan tingkat pendapatan anggota poktan bersertifikat dan tidak bersertifikat organik, (2) Mendapat gambaran tentang penerapan ICS pada Gapoktan Simpatik, dan (3) Menganalisis persepsi anggota terhadap penerapan ICS, baik bersertifikat maupun belum bersertifikat organik.

\section{METODOLOGI}

Penelitian ini bersifat studi kasus dengan penentuan lokasi kajian dilakukan secara sengaja, yaitu Gapoktan yang telah menerapkan sertifikasi organik dengan pola ICS. Salah satu Gapoktan yang telah menerapkan ICS adalah Gapoktan Simpatik di Kabupaten Tasikmalaya, Jawa Barat. Gapoktan Simpatik merupakan gabungan 28 poktan yang terdiri dari 2.333 orang anggota. Berdasarkan penilaian IMO tahun 2009 dari jumlah tersebut, 11 kelompok bersertifikat organik, 3 poktan dalam tahap konversi, dan 14 kelompok belum bersertifikat (konvensional). Oleh karena itu, pada poktan yang berada dalam satu kecamatan, yaitu Kecamatan Sukahening. Poktan bersertifikat organik yang dijadikan contoh adalah poktan Srilangen 2 dari Desa Kiara Jangkung dan poktan Mekarjaya dari Desa Sunda Kerta, sedangkan kelompok yang belum bersertifikat adalah poktan Srilangen 1 dari Desa Kiara Jangkung dan poktan Sribangkit 2 dari Desa Sundakerta. Total jumlah petani yang bersertifikat organik adalah 131 orang dan yang belum bersertifikat 110 orang. Pemilihan lokasi ini didasarkan pertimbangan kedua desa saling berdekatan dan memiliki sumber perairan yang tidak jauh berbeda, yaitu sama-sama berada di daerah hulu Sungai Cideres dan Sungai Cigunungjaga, sehingga memungkinkan mendapatkan air yang relatif belum terkontaminasi. Dengan demikian keberhasilan disertifikasi atau tidaknya keduanya memiliki peluang yang hampir sama. Penelitian dilaksanakan mulai bulan September hingga Desember 2010.

Data dan informasi yang dikumpulkan terdiri atas data primer dan sekunder yang bersifat kualitatif dan kuantitatif. Metode pengambilan data dilakukan dengan cara interview langsung menggunakan kuesioner kepada pengurus Gapoktan dan ICS, pengurus poktan, inspektor internal dan petani, observasi dengan melihat dan mengamati secara langsung kondisi dan pelaksanaan di lapang dan membandingkan dengan teori yang ada.

Contoh diambil dari dua kelompok yang berbeda, yaitu petani bersertifikat organik dan tidak bersertifikat organik dalam satu kecamatan yang sama, yaitu Kecamatan Sukahening. Masingmasing poktan, baik bersertifikat maupun tidak bersertifikat organik diambil contoh 20 orang, sehingga total responden 80 orang. Penyebaran kuesioner dilakukan dengan metode judgement sampling, yaitu memilih responden yang paling tepat untuk mendapatkan informasi yang dibutuhkan.

Analisis data dilakukan secara kualitatif dan kuantitatif. Analisis kualitatif digunakan untuk mengetahui kondisi umum Gapoktan Simpatik dan data lainnya. Analisis kuantitatif meliputi:

1. Analisis pendapatan usahatani, dihitung dengan rumus berikut:

$$
P=T R-T C
$$

Keterangan:

$\mathrm{Pd}=$ Pendapatan usahatani

$\mathrm{TR}=$ Total revenue (total penerimaan)

$\mathrm{TC}=$ Total cost (total biaya)

Untuk kedua jenis usahatani dilakukan analisis imbangan penerimaan dan biaya $(R / C$ ratio analysis) dengan rumus berikut:

Keterangan:

$$
a=\frac{R}{C \text { ? }}
$$

$\mathrm{a}=R /$ C ratio

$\mathrm{R}=$ Total penerimaan

$\mathrm{C}=$ Total biaya

2. Analisis Perbedaan Pendapatan Usahatani

Untuk melakukan uji perbedaan pendapatan dilakukan dengan uji hipotesis maka hipotesis yang dirumuskan dengan harapan akan ditolak membawa penggunaan istilah 
hipotesis nihil (Ho) yang mengakibatkan penerimaan suatu hipotesis alternatif $(\mathrm{Ha}, \mathrm{H} 1$ atau $\mathrm{Hi}$ ).

3. Analisis Persepsi Anggota terhadap Penerapan ICS

Analisis ini bertujuan untuk mengetahui sikap anggota, baik dari kelompok bersertifikat organik dengan tidak bersertifikat terhadap penerapan ICS. Kelompok yang akan diamati meliputi poktan Srilangen 1 dan Srilangen 2 dari Desa Kiara Jangkung dan poktan Mekarjaya dan Sribangkit 2 dari Desa Sunda Kerta. Peubah (Tabel 1) yang diamati berdasarkan pada panduan ICS organik yang telah dikeluarkan oleh IFOAM.

Sikap responden ditentukan dengan mengajukan pertanyaan yang terkait dengan peubah dalam bentuk skala likert. Penentuan skor atau nilai berdasarkan alternatif jawaban yang telah ditetapkan, yakni 5 alternatif jawaban seperti dimuat pada Tabel 2.

Tabel 1. Peubah pengamatan penerapan ICS pada poktan

\begin{tabular}{cl}
\hline Kode & \multicolumn{1}{c}{ Uraian } \\
\hline X1 & Mengelola kemutahiran dan pendistribusian \\
& panduan ICS \\
X2 & Uraian struktur dan kegiatan kelompok \\
X3 & Manajemen risiko \\
X4 & Standar organik internal yang digunakan \\
X5 & Pengawasan lahan dan prosedur persetujuan \\
X6 & Personel organisasi dan ICS \\
X7 & Pelatihan \\
X8 & Pembelian, penanganan, pengolahan dan \\
& ekspor \\
X9 & Inspeksi dan sertifikasi eksternal \\
\hline
\end{tabular}

Tabel 2. Skor dari alternatif jawaban

\begin{tabular}{ll}
\hline Alternatif Jawaban & Skor Positif \\
\hline Sangat tidak puas/sangat & 1 \\
tidak paham & \\
Tidak puas/tidak paham & 2 \\
Cukup puas/cukup paham & 3 \\
Puas/paham & 4 \\
Sangat puas/sangat paham & 5 \\
\hline
\end{tabular}

Hasil kuesioner selanjutnya dianalisis biplot untuk mendapatkan gambaran tentang persepsi anggota bersertifikat dan tidak bersertifikat terhadap penerapan ICS. Responden dari masingmasing kelompok diberi nomor berbeda untuk memudahkan dalam mengamati persepsinya terhadap peubah yang diamati. Kelompok yang bersertifikat organik diberi nomor R1-R40, dengan rincian R1-R20 untuk poktan Srilangen 2 dan R21R40 untuk poktan Mekarjaya. Poktan yang belum bersertifikat juga diberi nomor R1-R40 dengan rincian R1-R20 untuk poktan Srilangen 1, dan R21-R40 untuk responden dari poktan Sribangkit 2. Pengolahan data dilakukan dengan bantuan software SAS.

\section{HASIL DAN PEMBAHASAN}

Kecamatan Sukahening merupakan salah satu dari 39 kecamatan di Kabupaten Tasikmalaya. Kecamatan ini terdiri dari tujuh desa, yaitu Desa Kudadepa, Sundakerta, Kiarajangkung, Sukahening, Calingcing, Banyurasa dan Banyuresmi. Kedua desa ini merupakan desa yang letaknya paling tinggi dan berbatasan langsung dengan hutan rakyat, sehingga peluang menerapkan pertanian organik sangat memungkinkan.

Jumlah penduduk di Kecamatan Sukahening pada tahun 2007 tercatat 28.008 orang yang terdiri dari 14.116 orang laki-laki dan 14.132 orang perempuan. 3.519 orang merupakan warga Desa Sundakerta $(12,6 \%)$ dan 3.553 orang merupakan penduduk Desa Kiarajangkung (12,7\%). Sebanyak 77\% penduduk Kecamatan Sukahening berpenghasilan dari sektor pertanian dan sisanya dari sektor lain seperti perdagangan dan jasa. Tingkat pendidikan lebih didominasi oleh tamatan Sekolah Dasar (SD) 52,84\%, tingkat Sekolah Lanjutan Tingkat Pertama (SLTP) 32,43\%, Sekolah Lanjutan Tingkat Atas (SLTA) 8,47\% dan sisanya $(5,74 \%)$ belum atau tidak tamat.

Petani di Kecamatan Sukahening mulai mengenal pertanian organik dengan metode System of Rice of Intensification (SRI) sejak tahun 2001, namun penerapannya secara bertahap baru dimulai sejak tahun 2006. Sejak tahun 2001, kelembagaan petani ikut berkembang, terbukti dengan semakin banyaknya terbentuk poktan dari sebelumnya hanya 21 kelompok menjadi 32 kelompok atau meningkat $50 \%$. Salah satu poktan yang terbentuk di Desa Kiarajangkung sejak mengenal pertanian organik adalah poktan Srilangen 1 yang berdiri tahun 2001 dan Srilangen 2 yang berdiri tahun 2002, sedangkan di Desa Sundakerta terbentuk poktan Mekarjaya yang berdiri tahun 2001 dan poktan Sribangkit 2 yang berdiri tahun 2004 


\section{Karakteristik Poktan}

Berdasarkan tingkat usia, untuk kelompok petani yang bersertifikat organik, 47,5\% merupakan petani dengan usia 32-48 tahun, 50\% berusia 49-64 tahun, dan sisanya 2,5\% berusia di atas 64 tahun. Poktan yang tidak bersertifikat organik $42,5 \%$ berusia $32-48$ tahun, $50 \%$ berusia $49-64$ tahun dan $7,5 \%$ berusia di atas 64 tahun. Berdasarkan data tersebut, secara total usia petani adalah $45 \%$ berusia $32-48$ tahun, $50 \%$ berusia 49 64 tahun dan 5\% berusia lebih dari 64 tahun. Menurut Wirosoehardjo (1981) batasan usia produktif penduduk 15-64 tahun maka 95\% petani berada dalam usia produktif.

Berdasarkan tingkat pendidikan, 95\% poktan bersertifikat organik merupakan petani dengan tingkat pendidikan tamatan SD, dan 5\% berpendidikan Sarjana (S1). Petani dari poktan yang tidak bersertifikat organik 97,5\% berpendidikan tamatan SD, dan 2,5\% SLTP. Poktan bersertifikat organik memiliki anggota berpendidikan S1, yang merupakan pengurus poktan, dan berperan besar sebagai motor penggerak dalam kelompok untuk menerapkan pertanian organik agar disertifikasi. Secara umum tingkat pendidikan pada semua kelompok relatif masih rendah, yaitu tamatan SD.

Berdasarkan tingkat tanggungan keluarga dari kelompok bersertifikat organik, 32,5\% kelompok yang memiliki tanggungan kurang dari 3 orang, $60 \%$ memiliki tanggungan 3-5 orang dan $7,5 \%$ memiliki tanggungan lebih dari 5 orang. Poktan tidak bersertifikat organik, 60\% memiliki tanggungan kurang dari 3 orang, 32,5\% memiliki tanggungan 3-5 orang dan 7,5\% memiliki tangggungan lebih dari 5 orang. Secara keseluruhan, 46,5\% memiliki tanggungan kurang dari 3 orang, 46,5\% memiliki tanggungan 3-5 orang, dan 7,5\% memiliki tanggungan lebih dari 5 orang.

Berdasarkan luas lahan organik yang diusahakan, diperoleh data bahwa untuk kelompok bersertifikat maupun tidak bersertifikat organik, sebagian besar memiliki lahan sempit, yaitu kurang dari 0,25 ha. Kelompok bersertifikat organik, 62,5\% memiliki lahan kurang dari 0,25 ha, 32,5\% memiliki lahan 0,25-0,5 ha, 5\% memiliki lahan $0,51-0,75$ ha dan tak seorangpun yang memiliki lahan lebih dari 0,75 ha. Kepemilikan lahan yang tidak bersertifikat organik, 66,25\% memiliki lahan kurang dari 0,25 ha, 31,25\% memiliki lahan 0,26-0,50 ha dan tak satupun yang memiliki lahan lebih dari 0,5 ha. Kepemilikan lahan yang makin sempit ini berpengaruh terhadap tingkat pendapatan petani, karena akan menyebabkan kurang efisiennya usahatani yang diusahakan. Rataan luas lahan untuk kelompok bersertifikat organik adalah 0,24 ha, sedangkan untuk petani yang belum bersertifikat organik luas rataan 0,19 ha. Apabila dilihat dari status kepemilikan lahan, semua lahan yang dimiliki merupakan lahan milik sendiri. Sebagian besar mencukupi kebutuhan hidupnya dengan melakukan pekerjaan sampingan seperti menjadi buruh upah dan pedagang.

Petani organik yang telah bersertifikat maupun tidak bersertifikat memiliki perbedaan dari lamanya pengalaman dalam bertani organik. Dari data yang diamati, untuk kelompok bersertifikat organik, semuanya merupakan petani yang telah menerapkan pertanian organik lebih dari tiga tahun, sedangkan kelompok yang belum bersertifikat organik semuanya memiliki pengalaman bertani organik kurang dari tiga tahun.

\section{Analisis Pendapatan Usahatani}

\section{Biaya Usahatani}

Pendapatan usahatani sangat dipengaruhi oleh biaya yang dikeluarkan, baik biaya variabel maupun biaya tetap. Komponen biaya variabel pada pertanian organik yang bersertifikat maupun tidak bersertifikat adalah sama, yaitu mencakup biaya untuk pembelian benih, pupuk, pestisida nabati/organik, dan tenaga kerja.

Berdasarkan data rataan dari poktan bersertifikat organik, komponen biaya variabel yang paling banyak adalah untuk pupuk, yaitu Rp9.224.000/ha/tahun atau 57,6\% dari total biaya variabel, tenaga kerja Rp5.960.000/ha/tahun (37,3\%), pestisida nabati Rp743.400/ha/tahun $(4,6 \%)$, dan biaya untuk benih Rp72.800/ha/tahun $(0,5 \%)$. Komponen biaya variabel dari kelompok tidak bersertifikat organik yang terbanyak adalah untuk pupuk Rp7.272.400/ha/tahun atau 49\% dari total biaya variabel, biaya tenaga kerja Rp6.758.000/ha/tahun (45,5\%), pestisida nabati Rp722.400/ha/tahun (4,9\%) dan untuk benih Rp93.260/ha/tahun (0,6\%).

Komponen biaya variabel untuk benih pada kedua kelompok menunjukkan bahwa kelompok bersertifikat organik mengeluarkan biaya yang lebih murah Rp20.460/ha/tahun dibandingkan kelompok yang tidak bersertifikat. Untuk komponen biaya pupuk, kelompok bersertifikat mengeluarkan biaya yang lebih besar dengan perbedaan Rp1.951.600/ha/tahun. Dominannya biaya pupuk pada kelompok bersertifikat organik, mengguna- 
kan pupuk kandang dan pupuk hijauan, sedangkan kelompok tidak bersertifikat hanya menggunakan pupuk kandang. Komponen biaya pestisida nabati/organik pada kelompok bersertifikat mempunyai biaya sedikit lebih tinggi dari kelompok yang tidak bersertifikat, yaitu Rp21.000/ha/tahun. Komponen untuk biaya tenaga kerja, terlihat bahwa poktan tidak bersertifikat organik mengeluarkan biaya yang relatif lebih tinggi dari poktan bersertifikat organik, yaitu Rp798.000/ha/tahun. Data lengkap untuk biaya variabel rataan pada masing-masing kelompok terdapat dalam Tabel 3.

Komponen biaya tetap untuk pertanian padi organik dalam penelitian mencakup biaya untuk sewa peralatan, penyusutan peralatan, pajak, dan biaya lahan. Berdasarkan data rata-rata biaya tetap untuk kedua kelompok relatif sama, karena alat yang digunakan, sewa lahan, dan pajak lahan adalah relatif sama (Tabel 4).

Komponen biaya tetap terbesar berasal dari sewa lahan, yaitu Rp6.928.000/ha/tahun atau $76,6 \%$. Biaya tetap lainnya adalah sewa peralatan Rp997.500/ha/tahun atau 11\%, pajak Rp714.000 atau $7,9 \%$ dan penyusutan peralatan Rp402.500/ ha/tahun atau $4,5 \%$.

Berdasarkan total keseluruhan biaya (biaya variabel dan biaya tetap), untuk pertanian organik dari kelompok yang bersertifikat rataan mempunyai biaya total Rp25.042.000/ha/tahun, sedangkan tidak bersertifikat Rp23.888.060/ha/tahun, atau ada perbedaan biaya total Rp1.154.140/ha/ tahun. Tabel 5 memperlihatkan total biaya/ha/ tahun yang dikeluarkan oleh kedua kelompok.

\section{Penerimaan Usahatani}

Rataan penerimaan usahatani untuk kedua kelompok memperlihatkan perbedaan cukup nyata, karena produktivitas per hektar untuk kelompok bersertifikat cenderung lebih tinggi dari kelompok tidak bersertifikat. Rataan produktivitas untuk kelompok bersertifikat adalah 6,005 ton/ha, sedangkan untuk yang tidak bersertifikat adalah 5,231 ton/ha. Hal ini diperkirakan karena penggunaan pupuk yang lebih banyak dan juga penerapan bertani organik kelompok ini yang jauh lebih lama dari kelompok yang tidak bersertifikat. Mamaril dalam Syam (2008) mengungkapkan bahwa bahan organik yang digunakan secara terus menerus dan kurun waktu yang lama akan dapat meningkatkan bahan organik di dalam tanah. Hal ini tentunya akan berpengaruh kepada kesuburan tanah dan tanaman.

Tabel 3. Rataan biaya variabel/hektar/tahun

\begin{tabular}{|c|c|c|c|c|c|}
\hline \multirow{3}{*}{$\begin{array}{c}\text { Komponen } \\
\text { Biaya }\end{array}$} & \multicolumn{4}{|c|}{ Jenis Kelompok } & \multirow{3}{*}{$\begin{array}{c}\text { Perbedaan } \\
\text { (Rp/ha/ } \\
\text { tahun) }\end{array}$} \\
\hline & \multicolumn{2}{|c|}{ Bersertifikat } & \multicolumn{2}{|c|}{ Tidak Bersertifikat } & \\
\hline & $\begin{array}{r}\text { Jumlah } \\
\text { (Rp/ha/thn) }\end{array}$ & $\begin{array}{r}\text { Persentase } \\
(\%) \\
\end{array}$ & $\begin{array}{r}\text { Jumlah } \\
\text { (Rp/ha/thn) }\end{array}$ & $\begin{array}{r}\text { Persentase } \\
(\%) \\
\end{array}$ & \\
\hline Benih & 72.800 & 0,5 & 93.260 & 0,6 & 20.460 \\
\hline Pupuk & 9.224 .000 & 57,6 & 7.272 .400 & 49,0 & 1.951 .600 \\
\hline Pestisida nabati & 743.400 & 4,6 & 722.400 & 4,9 & 21.000 \\
\hline Tenaga kerja & $(5.960 .000)$ & 37,3 & $(6.758 .000)$ & 45,5 & -798.000 \\
\hline Jumlah & 16.000 .200 & 100 & 14.846 .060 & 100 & 1.154 .140 \\
\hline
\end{tabular}

Sumber: Data primer diolah (2011).

Tabel 4. Rataan biaya tetap/hektar/tahun

\begin{tabular}{|c|c|c|c|c|c|}
\hline \multirow{3}{*}{ Komponen biaya } & \multicolumn{4}{|c|}{ Jenis kelompok } & \multirow{3}{*}{$\begin{array}{c}\text { Perbedaan } \\
\text { (Rp/ha/ } \\
\text { tahun) }\end{array}$} \\
\hline & \multicolumn{2}{|c|}{ Bersertifikat } & \multicolumn{2}{|c|}{ Tidak bersertifikat } & \\
\hline & $\begin{array}{c}\text { Jumlah } \\
\text { (Rp/ha/thn) }\end{array}$ & $\begin{array}{c}\text { Persentase } \\
(\%)\end{array}$ & $\begin{array}{c}\text { Jumlah } \\
\text { (Rp/ha/thn) }\end{array}$ & $\begin{array}{c}\text { Persentase } \\
(\%)\end{array}$ & \\
\hline Sewa lahan & 6.928 .000 & 76,6 & 6.928 .000 & 76,6 & 0 \\
\hline Sewa peralatan & 1.000 .000 & 11,1 & 995.000 & 11,0 & 5.000 \\
\hline Penyusutan peralatan & 400.000 & 4,4 & 405.000 & 4,5 & -5.000 \\
\hline Pajak & 714.000 & 7,9 & 714.000 & 7,9 & 0 \\
\hline Jumlah & 9.042 .000 & 100 & 9.042 .000 & 100 & 0 \\
\hline
\end{tabular}

Sumber: Data primer diolah (2011). 
Tabel 5. Total Biaya/hektar/tahun

\begin{tabular}{|c|c|c|c|c|c|}
\hline \multirow{3}{*}{$\begin{array}{c}\text { Komponen } \\
\text { Biaya }\end{array}$} & \multicolumn{4}{|c|}{ Jenis Kelompok } & \multirow{3}{*}{$\begin{array}{l}\text { Rataan } \\
\text { (Rp/ha/ } \\
\text { tahun) }\end{array}$} \\
\hline & \multicolumn{2}{|c|}{ Bersertifikat } & \multicolumn{2}{|c|}{ Tidak Bersertifikat } & \\
\hline & $\begin{array}{c}\text { Jumlah } \\
\text { (Rp/ha/thn) }\end{array}$ & $\begin{array}{c}\text { Persentase } \\
(\%)\end{array}$ & $\begin{array}{c}\text { Jumlah } \\
\text { (Rp/ha/thn) }\end{array}$ & $\begin{array}{l}\text { Persentase } \\
(\%)\end{array}$ & \\
\hline Biaya variabel & 16.000 .200 & 63,9 & 14.846 .060 & 62,1 & 1.154 .140 \\
\hline Biaya tetap & 9.042 .000 & 36,1 & 9.042 .000 & 37,9 & 0 \\
\hline Jumlah & 25.042 .200 & 100 & 23.888 .060 & 100 & 1.154 .140 \\
\hline
\end{tabular}

Sumber: Data primer diolah (2011).

Tabel 6. Pendapatan/tahun kelompok bersertifikat organik dan tidak bersertifikat organik

\begin{tabular}{lrcr}
\hline \multicolumn{1}{c}{ Uraian } & $\begin{array}{c}\text { Bersertifikat } \\
\text { Organik (a) }\end{array}$ & $\begin{array}{c}\text { Tidak bersertifikat } \\
\text { Organik (b) }\end{array}$ & $\begin{array}{c}\text { Perbedaan } \\
\text { (a-b) }\end{array}$ \\
\hline Produksi (ton/tahun) & 12,01 & 10,462 & 1,548 \\
Harga (Rp/ton) & 3.700 .000 & 3.500 .000 & 200.000 \\
Penerimaan (Rp/tahun) & 44.437 .000 & 36.617 .000 & 7.820 .000 \\
Biaya (Rp/tahun) & 25.042 .200 & 23.888 .060 & -1.154 .140 \\
Pendapatan (Rp/tahun) & 19.394 .800 & 12.728 .940 & 6.665 .860 \\
\hline
\end{tabular}

Sumber: Data primer diolah (2011).

Harga jual padi organik kelompok bersertifikat dan yang tidak bersertifikat terdapat perbedaan Rp200.000/ton. Gabah kering panen dari kelompok bersertifikat organik dibeli oleh ICS dengan harga Rp3.700.000/ton, sedangkan untuk kelompok tidak bersertifikat harga yang diterima baik dari ICS maupun bandar lokal rataan Rp3.500.000/ton. Perbedaan ini dapat dipahami karena kelompok bersertifikat organik dianggap dapat memberikan jaminan keorganikan lebih baik daripada kelompok yang tidak bersertifikat organik, namun harga ini masih lebih rendah dari yang diharapkan, yaitu minimal Rp500.000/ton. Walaupun harga yang diperoleh belum maksimal sesuai dengan harapan, namun harga tersebut masih lebih baik dari petani konvensional yang rataan harganya Rp3.200.000/ton.

Penerimaan usahatani dihitung berdasarkan penerimaan per tahun. Semua kelompok melakukan pemanenan sebanyak dua kali dalam satu tahun. Berdasarkan penerimaan usahatani rataan, kelompok bersertifikat memperoleh penerimaan Rp44.437.000/ha/tahun, sedangkan yang tidak bersertifikat Rp36.617.000/ha/ tahun, sehingga ada perbedaan penerimaan diantara dua kelompok Rp7.820.000/ha/tahun.

Total penerimaan usahatani setelah dikurangi dengan total biaya menghasilkan total pendapatan. Kelompok bersertifikat organik memperoleh pendapatan Rp19.394.800 ha/tahun, sedangkan kelompok yang tidak bersertifikat organik mempunyai pendapatan Rp12.728.940/ ha/tahun atau ada perbedaan pendapatan sebesar Rp6.665.860/ha/tahun (Tabel 6).

\section{Analisis R/C ratio}

Kelompok yang bersertifikat organik memperoleh nilai $\mathrm{R} / \mathrm{C}$ ratio 1,77 , berarti setiap 1 rupiah yang dikeluarkan akan mampu memberikan penerimaan 1,77 rupiah. Nilai R/C lebih dari 1 menunjukkan bahwa usahatani poktan yang bersertifikat organik menguntungkan untuk diusahakan.

Nilai R/C untuk poktan tidak bersertifikat organik adalah 1,53 yang berarti usahatani ini juga menguntungkan. Apabila dibandingkan dengan nilai $\mathrm{R} / \mathrm{C}$ ratio kelompok yang bersertifikat, maka nilai ini lebih rendah 0,24 , berarti tingkat kemampuan kelompok tidak bersertifikat untuk mengembalikan penerimaan dari total biaya yang dikeluarkan 0,24 kali lebih kecil dari kelompok yang bersertifikat organik. Perhitung-an nilai R/C ratio dimuat dalam Tabel 7.

Tabel 7. Nilai R/C ratio kelompok bersertifikat organik dan tidak bersertifikat organik

\begin{tabular}{lccc}
\hline Uraian & $\begin{array}{c}\text { Bersertifikat } \\
\text { (a) }\end{array}$ & $\begin{array}{c}\text { Tidak } \\
\text { bersertifikat } \\
\text { (b) }\end{array}$ & $\begin{array}{c}\text { Perbedaan } \\
\text { (a-b) }\end{array}$ \\
\hline $\begin{array}{l}\text { Penerimaan } \\
\text { Rp/tahun) }\end{array}$ & 44.437 .000 & 36.617 .000 & 7.820 .000 \\
$\begin{array}{l}\text { Biaya (Rp/ } \\
\text { tahun) }\end{array}$ & 25.042 .200 & 23.888 .060 & -1.154 .140 \\
\hline $\begin{array}{l}\text { R/C ratio } \\
\text { Sumber: Data primer diolah (2011). }\end{array}$ & 1,53 & 0,24 \\
\hline
\end{tabular}




\section{Analisis Perbedaan Pendapatan}

Analisis perbedaan pendapatan dengan menggunakan uji $t$ dua contoh independen dilakukan apabila asumsi data tersebar normal terpenuhi. Pengujian kenormalan data dilakukan menggunakan uji Kolmogorov-Smirnov. Uji ini menggunakan hipotesis dua arah, yaitu $\mathrm{H}_{0}: \mu_{1}-\mu_{2}$ $=\delta_{0}$ dan $\mathrm{H}_{1}: \mu_{1}-\mu_{2} \neq \delta_{0}$ dengan daerah kritis untuk menolak $\mathrm{H}_{0}$ jika $\left|\mathrm{th}_{\mathrm{h}}\right|>\mathrm{t}_{(\alpha / 2)}$ atau $\mathrm{p}$-value $<$ alfha (a) 0,05. Berdasarkan hasil pengujian menggunakan Statistical Package for Social Science (SPSS), diperoleh hasil bahwa data pendapatan dari kelompok bersertifikat organik tidak tersebar secara normal yang ditunjukkan dengan nilai nyata 0,024 yang lebih kecil dari $\alpha=0,05$, artinya menolak $\mathrm{H}_{0}$ dan terima $\mathrm{H}_{1}$ bahwa data pendapatan petani dari kelompok bersertifikat organik tidak tersebar secara normal. Untuk data pendapatan dari kelompok yang tidak bersertifikat organik diperoleh nilai nyata 0,200 yang lebih besar dari $\alpha=0,05$, berarti menerima $\mathrm{H}_{0}$ bahwa data tingkat pendapatan kelompok tidak bersertifikat organik tersebar normal. Data lengkap hasil uji kenormalan Kolmogorov-Smirnov terdapat dalam Tabel 8.

Tabel 8. Hasil uji kenormalan data tingkat pendapatan kelompok bersertifikat organik dan tidak bersertifikat organik

Tests of Normality Kolmogorov-Smirnov ${ }^{a}$

\begin{tabular}{llll}
\hline & Statistic & df & Sig. \\
\hline Sertifikat & 0,150 & 40 & 0,024 \\
Belum Sertifikat & 0,086 & 40 & $0,200^{*}$ \\
\hline
\end{tabular}

a. Lilliefors Significance Correction

*. This is a lower bound of the true significance.
Sesuai dengan hasil uji kenormalan yang diperoleh maka persyaratan untuk melakukan uji $\mathrm{t}$ dua contoh independen tidak dapat dipenuhi, sehingga pengujian perbedaan tingkat pendapatan antara dua kelompok dilakukan dengan menggunakan uji non parametrik Mann-Whitney yang tidak mempersyaratkan data harus tersebar normal. Pengujian ini menggunakan uji hipotesis dua arah, yaitu $\mathrm{H}_{0}: \mu=\mu_{i}$ yang berarti tidak ada perbedaan rataan diantara kedua contoh dan $\mathrm{H}_{1}$ : $\mu \neq \mu_{\mathrm{i}}$ yaitu terdapat perbedaan rataan antara kedua contoh. Kaidah yang dilakukan untuk mengambil keputusan adalah menolak $\mathrm{H}_{0}$, jika nilai nyata $<0,00$ dan terima $\mathrm{H}_{0}$, jika nilai nyata $>0,00$. Dari output Rank, dapat dilihat bahwa nilai rataan untuk data bersertifikat lebih besar daripada nilai rataan data yang belum bersertifikat (56.18 > 24.82), berarti tingkat pendapatan kelompok bersertifikat lebih besar daripada kelompok tidak bersertifikat.

Pengujian analisis perbedaan pendapatan dua kelompok independen dengan uji MannWhitney $U$, diperoleh hasil nilai statistik uji $Z$ yang sangat kecil $(-6.033)$ dan nilai nyata dua arah adalah $0.000<0,05$, artinya hipotesis $\mathrm{H}_{0}$ ditolak, yaitu terdapat perbedaan nilai dugaan rataan total pendapatan antara kelompok bersertifikat dengan kelompok yang belum bersertifikat. Data lengkap hasil pengujian ini dimuat pada Tabel 9.

Sesuai dengan hasil analisis perbedaan pendapatan, kelompok bersertifikat memiliki pendapatan lebih tinggi dari kelompok tidak bersertifikat. Hal ini merupakan salah satu keuntungan dari penerapan ICS yang berhasil disertifikasi, yaitu harga jual lebih tinggi dan jaminan pemasaran lebih baik. Pendapatan yang lebih baik ini juga dipengaruhi oleh biaya

Tabel 9. Hasil uji perbedaan pendapatan antara kelompok bersertifikat organik dan tidak bersetifikat organik

Ranks

\begin{tabular}{llrrr}
\hline & JENIS & $\mathrm{N}$ & Mean Rank & Sum of Ranks \\
\hline PENDAPATAN & KELOMPOK BELUM & 40 & 24.82 & 993.00 \\
& BERSERTIFIKAT & & 56.18 & 2.247 .00 \\
\cline { 2 - 5 } & KELOMPOK BERSERTIFIKAT & 40 & & \\
\cline { 2 - 4 } & Total & 80 & & \\
\hline
\end{tabular}

Test Statistik ICS ${ }^{a}$

\begin{tabular}{lr}
\hline & PENDAPATAN \\
\hline Mann-Whitney U & 173.000 \\
\hline$Z$ & -6.033 \\
\hline Asymp. Sig. (2-tailed) & .000 \\
\hline
\end{tabular}

a. Grouping Variable: JENIS 
sertifikasi yang tidak dibebankan kepada petani. Biaya sertifikasi pada kelompok ini difasilitasi oleh traider yang bekerjasama dengan Gapoktan Simpatik dan bantuan dari Pemerintah Daerah (pemda). Disatu sisi, hal ini sangat menguntungkan bagi kelompok karena tidak perlu mengeluarkan biaya sertifikasi, namun di sisi lain Gapoktan memiliki kelemahan akibat tidak leluasa membeli gabah petani dengan harga yang sesuai dengan harapan anggota. Hal ini terjadi karena Gapoktan terikat dengan harga kontrak yang telah ditangani dengan traider. Meskipun perjanjian harga ini dievaluasi setiap satu tahun untuk menyesuaikan dengan perkembangan harga di pasaran, namun dengan kondisi saat ini yang mana harga gabah meningkat drastis dalam waktu yang sangat singkat, maka ada baiknya perjanjian tersebut dievaluasi dalam waktu lebih singkat.

Mengingat segala biaya sertifikasi masih ditanggung oleh pihak luar maka untuk meningkatkan kemandirian poktan dan Gapoktan perlu dilakukan penyisihan keuntungan, dengan tujuan untuk membiayai sertifikasi secara mandarin, sehingga Gapoktan lebih leluasa menentukan kebijakannya dan mencapai tujuannya, yaitu mensejahterakan petani anggotanya. Hal ini penting untuk menarik minat poktan organik lainnya yang belum bersertifikat untuk bergabung dan memperoleh sertifikat organik.

\section{Penerapan Internal Control System}

Penerapan ICS pada semua kelompok, baik yang bersertifikat dan tidak bersertifikat dimulai sejak tahun 2008. Tujuan penerapan ini untuk memperoleh sertifikat organik dari lembaga sertifikasi. Langkah awal dari penerapan ICS ini adalah pengenalan dan pelatihan ICS kepada perwakilan poktan yang tertarik untuk disertifikasi. Personil yang telah paham tentang organik dan persyaratan ICS diangkat sebagai personil ICS dan dipimpin oleh seorang koordinator ICS. Personil ICS mempunyai tugas menyusun dokumen yang diperlukan untuk memenuhi persyaratan sertifikasi dengan pola ICS seperti data petani, status lahan, status penggunaan pupuk dan pestisida kimia, pedoman ICS yang akan menjadi pedoman bagi penerapan ICS di kelompok sesuai dengan panduan umum ICS yang dikeluarkan oleh IFOAM.

Pedoman ICS merupakan panduan bagi semua anggota dalam menerapkan pertanian organik anggota ICS. Panduan ICS yang dimiliki Gapoktan Simpatik mencakup:

\section{Distribusi dan Revisi Pedoman ICS}

Pedoman ICS disusun dalam bentuk yang mudah dimengerti dan dibagikan kepada semua Manajemen ICS (Koordinator dan staf ICS), semua anggota Komisi Pengambil Keputusan, seluruh Inspektor Internal dan Staf Lapangan. Bagianbagian tertentu dari pedoman ICS Gapoktan Simpatik juga dibagikan atau didistribusikan kepada seluruh petani, bagian teknis/pengolahan/ pemrosesan, dan bagian pemasaran. Sedikitnya sekali dalam setahun sebelum musim panen padi organik, yaitu sekitar bulan Januari, Pedoman ICS Gapoktan diperiksa ulang dan disesuaikan dengan perubahan-perubahan yang diperlukan.

\section{Uraian Struktur dan Kegiatan}

Program sertifikasi lahan padi organik dilaksanakan oleh Gapoktan Simpatik selaku pelaksana ICS, sedangkan kegiatan External Control dilaksanakan oleh IMO, Swiss. Kepengurusan Gapoktan berasal dari semua wilayah yang ikut dalam proses sertifikasi. Setiap wilayah ditempatkan beberapa orang inspektor yang mengawasi 50-60 orang petani yang berasal dari daerah yang berbeda dengan asalnya. Alur produksi pemasaran padi organik dilakukan dengan cara berikut:

a. Pemanenan oleh petani disaksikan oleh Petugas ICS

b. Hasil panen dikumpulkan dalam bentuk Gabah Kering Panen (GKP) atau Gabah Kering Giling (GKG) di lokasi gudang kelompok

c. Pengangkutan dari gudang poktan ke tempat penampungan dilakukan oleh ICS

d. Pengeringan Gabah Kering Panen (GKP) dilakukan oleh ICS

e. Proses penggilingan, penyortiran, pengemasan dan pelabelan oleh Gapoktan

f. Stuffing/pengemasan ke dalam kontainer oleh Gapoktan

g. Pengangkutan dari gudang Gapoktan oleh pihak mitra

h. Proses pengiriman hingga ke importir (shipping) oleh pihak mitra

\section{Manajemen Risiko}

Identifikasi awal tentang risiko harus lengkap, identifikasi risiko harus dilakukan di lahan, teknik budidaya tanaman, pemanenan, pengolahan pasca-panen pengiriman/transportasi bahkan kegiatan ekspor, jika masih di bawah kontrol ICS (Tabel 10). 
Tabel 10. Risiko-risiko penting sistem pertanian padi organik Gapoktan Simpatik

\begin{tabular}{|c|c|}
\hline RISIKO-RISIKO PENTING & CARA PENANGANANNYA \\
\hline $\begin{array}{l}\text { Pembibitan } \\
\text { - } \begin{array}{l}\text { Penggunaan pupuk kimia pada saat } \\
\text { pembibitan }\end{array} \\
\text { - Penggunaan media yang non- } \\
\text { organik (tanah) }\end{array}$ & $\begin{array}{l}\text { - Petani dilatih untuk membuat persemaian pada media semai } \\
\text { menggunakan campuran tanah dan pupuk organik, serta } \\
\text { dilakukan penyemprotan menggunakan Mikro Organisme Lokal } \\
\text { (MOL). }\end{array}$ \\
\hline $\begin{array}{l}\text { Penanaman } \\
\text { - } \quad \text { Bibit yang ditanam berasal dari bibit } \\
\text { yang non-organik } \\
\text { - Penanaman bibit non-organik di } \\
\text { lahan yang organik }\end{array}$ & 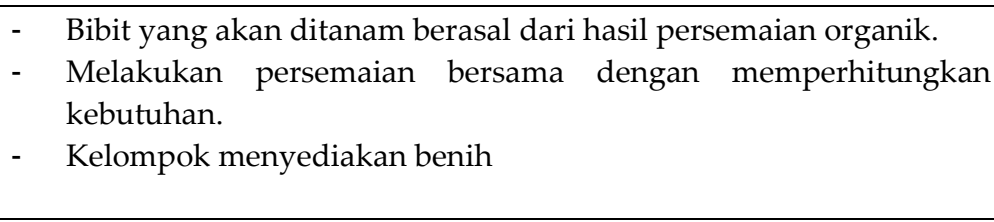 \\
\hline $\begin{array}{l}\text { Persiapan Lahan } \\
\text { - Pemakaian alsintan pada saat } \\
\text { persiapan lahan yang sudah tidak } \\
\text { layak pakai atau terkontaminasi } \\
\text { bahan kimia }\end{array}$ & $\begin{array}{l}\text { - Membuat kesepakatan bersama seluruh petani peserta pertanian } \\
\text { padi sistem organik untuk tidak menggunakan alsintan yang } \\
\text { sudah tidak layak pakai atau terkontaminasi bahan kimia. }\end{array}$ \\
\hline 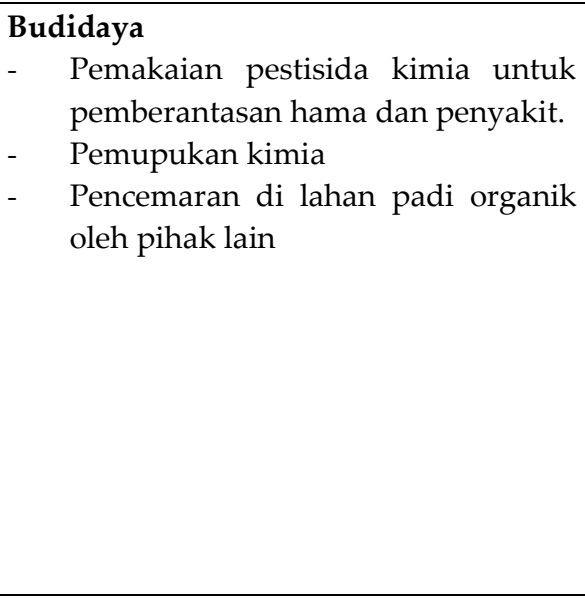 & 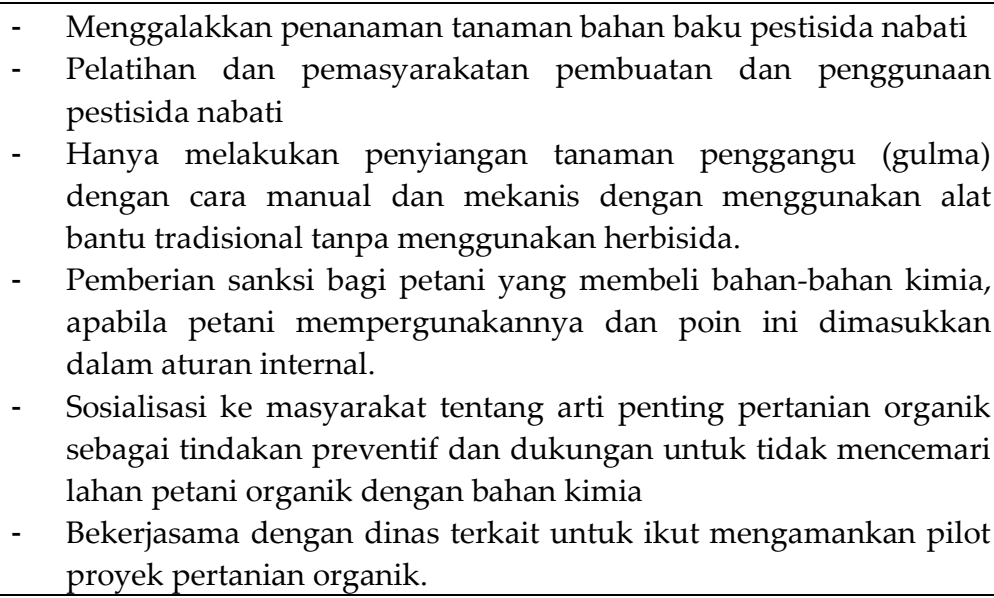 \\
\hline 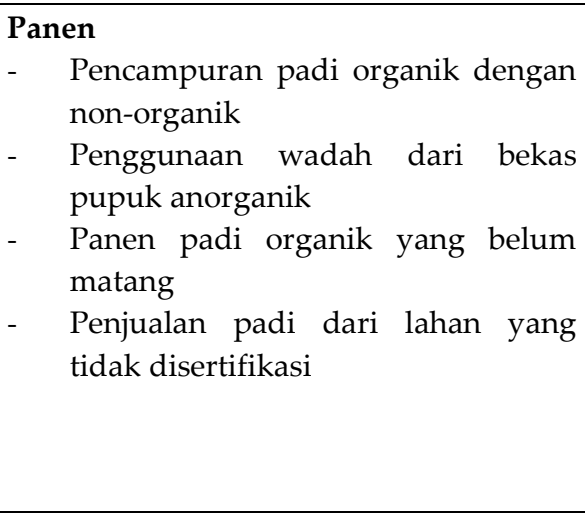 & 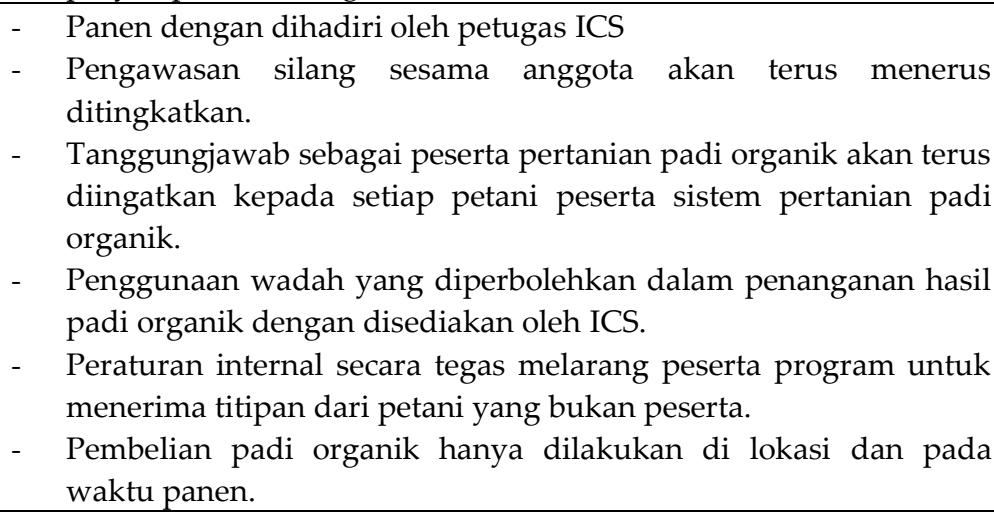 \\
\hline $\begin{array}{l}\text { Penyimpanan } \\
\text { - } \quad \text { Tercampurnya padi organik dan non- } \\
\text { organik } \\
\text { - Penggunaan wadah dan tempat } \\
\text { penyimpanan yang sama antara } \\
\text { organik dan non-organik. } \\
\text { - Lalai dalam memberi pelabelan } \\
\text { antara organik dan non-organik }\end{array}$ & 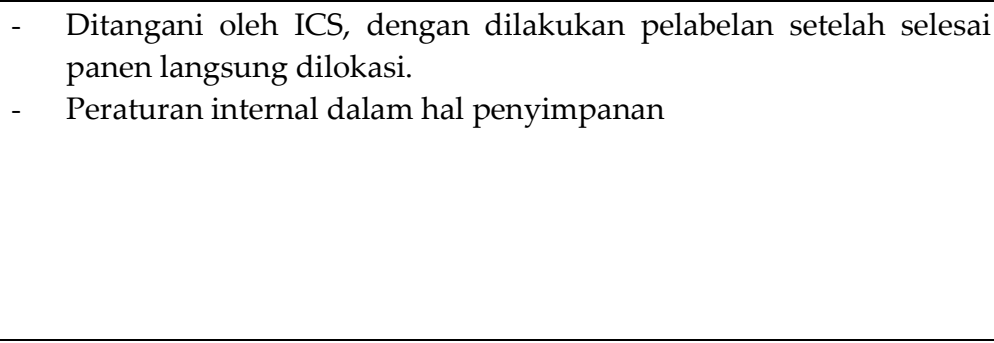 \\
\hline $\begin{array}{l}\text { Penjemuran } \\
\text { Lantai jemur atau tikar tercampur } \\
\text { dengan padi non-organik. }\end{array}$ & 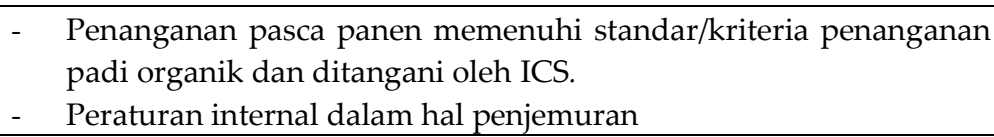 \\
\hline
\end{tabular}


Lanjutan Tabel 10.

\begin{tabular}{|c|c|}
\hline RISIKO-RISIKO PENTING & CARA PENANGANANNYA \\
\hline $\begin{array}{l}\text { Transportasi } \\
\text { Dalam pengangkutan tercampur } \\
\text { dengan produk non-organik } \\
\text { Lalai membuat pelabelan antara } \\
\text { organik dan non-organik }\end{array}$ & - $\quad$ Pengangkutan produk hanya ditangani oleh ICS. \\
\hline 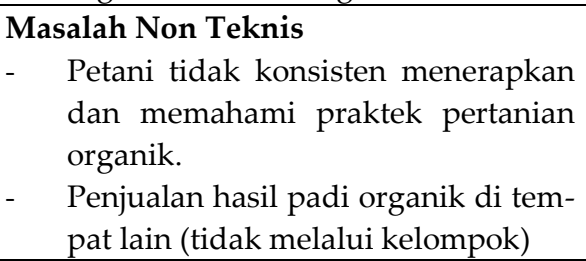 & $\begin{array}{l}\text { - Pemberian sangsi yang tegas bagi petani yang tidak } \\
\text { mengindahkan aturan sistem pertanian padi organik ICS. } \\
\text { - Petani akan menjual hasil padi organik ke kelompok, karena } \\
\text { harganya akan lebih mahal, namun demikian kebersamaan } \\
\text { kelompok akan terus dijaga. }\end{array}$ \\
\hline
\end{tabular}

Sumber: Gapoktan Simpatik (2011).

\section{Standar Internal Organik}

Standar internal organik yang dibuat oleh ICS mengacu kepada standar yang diberlakukan di negara tujuan. Tujuan utama pemasaran Gapoktan Simpatik adalah Uni Eropa dan United States of America (USA) sehingga standar internal yang disusun mengacu pada standar EURegulation 2092/91 dan USDA-NOP (Nasional Organik Program).

Untuk pemasaran dalam negeri, standar yang diacu adalah SNI sistem pangan organik dan harus mengikuti aturan pelabelan organik yang ditetapkan oleh Kelompok Kerja Organik Indonesia. Agar produk organik dapat dipasarkan dalam negeri dan diakui sertifikat organiknya maka harus sesuai dengan SNI 6729 : 2010 sistem pangan organik dan penilaiannya dilakukan oleh lembaga sertifikasi dalam negeri, sehingga dapat menggunakan logo organik Indonesia pada produknya. Untuk memenuhi persyaratan tersebut, Gapoktan juga telah berhasil mewujudkan beberapa poktan anggotanya memperoleh sertifikat dari lembaga sertifikasi dalam negeri.

Standar Internal Organik secara umum meliputi aturan tentang bagaimana pengelolaan/ budidaya tanaman padi organik (penggunaan benih, pupuk, konservasi lahan, perlindungan tanaman dari hama dan penyakit), sarana alsintan yang diperbolehkan dan yang dilarang, pencegahan kontaminasi dari irigasi dan hewan ternak, dan prosedur pemanenan dan prosedur pengolahan pasca panen.

\section{Prosedur Pengontrolan dan Pengambilan Keputusan}

Pengontrolan terhadap penerapan sistem pertanian organik dilakukan oleh inspektur ICS kepada semua petani yang tergabung dalam ICS. Pengontrolan dilakukan pada semua tahap mulai dari benih yang digunakan, tatacara budidaya, sarana prasarana yang digunakan termasuk gudang atau rumah petani yang digunakan untuk penyimpanan hasil produksi dan faktor lain yang mengandung risiko terkontaminasinya produk organik yang dihasilkan. Selain itu juga dibuat perkiraan hasil panen, sehingga dapat dijadikan kontrol pada saat petani melakukan penjualan ke ICS. Tujuannya menghindari adanya penyalahgunaan keanggotan ICS oleh petani dengan menjual hasil produksi lahan lain yang bukan dikelola dengan cara-cara organik kepada ICS. Pengontrolan dilakukan terhadap dokumen/ catatan petani dan pengecekan di lapangan.

Hasil pengontrolan yang dilakukan oleh inspektur disampaikan kepada komisi persetujuan untuk diputuskan. Komisi persetujuan pada Gapoktan Simpatik berjumlah sembilan orang. Komisi ini bertugas membandingkan hasil pengontrolan yang dilakukan petugas inspektor internal dengan data registrasi petani dan data hasil inspeksi internal sebelumnya. Bagi petani yang melakukan pelanggaran dilakukan beberapa tindakan, baik berupa sanksi atau tindakan perbaikan. Sanksi terberat adalah mengeluarkan petani dari keanggotaan ICS.

\section{Organisasi dan Staf}

Dalam organisasi ICS Gapoktan Simpatik diatur secara hirarki, dengan posisi dan pemaparan tugas yang jelas, sehingga organisasi ICS Gapoktan bisa berjalan dengan baik. Koordinator ICS Gapoktan Simpatik merupakan posisi yang penting untuk menjamin, agar program sertifikasi padi organik bisa diterapkan bagi seluruh poktan peserta program sertifikasi padi organik. Untuk itu, orang yang menempati posisi sebagai Koordinator ICS harus mempunyai kemampuan dalam pengelolaan administrasi, melatih dan mampu melakukan koordinasi dengan semua pihak yang berhubungan dengan 
program sertifikasi padi organik. Oleh karena itu dalam Gapoktan ini koordinator ICS berasal dari orang yang dipercaya banyak anggota dan merupakan petani kompeten dalam bidang organik, karena banyaknya pengalaman dan pelatihan yang diikutinya.

Untuk menjadi anggota inspektur internal dan komisi persetujuan, dibuat beberapa persyaratan sebagai kriteria untuk menjadi inspektur dan komisi persetujuan. Secara umum persyaratan tersebut mencakup pemahaman prinsip-prinsip pertanian organik dan Standar Internal Organik. Persyaratan lain untuk inspektur internal adalah bisa berbahasa lokal dan baca tulis, serta mengenal pola pertanian dan teknis budidaya organik di wilayah kerjanya. Untuk komisi persetujuan haruslah berasal dari orangorang yang dihormati dan disegani dalam kelompok.

Koordinator, anggota Komisi Persetujuan, Internal Inspektor dan Petugas Pembelian ICS Gapoktan merupakan posisi yang rawan dengan konflik kepentingan. Untuk menghindari terjadinya konflik kepentingan maka petugas yang duduk dalam posisi tersebut wajib menandatangani surat pernyataan konflik kepentingan.

\section{Pelatihan}

Pelatihan organik dilakukan secara rutin, terutama bagi petugas inspektur internal yang minimal dilakukan sekali dalam setahun. Bagi personil ICS lainnya pelatihan dilakukan sesuai dengan bidang tugasnya. Pelatihan bagi petani juga rutin dilakukan dengan tujuan meningkatkan kesadaran petani akan arti penting pertanian organik dan petani bersedia menerapkan pertanian organik dengan motivasi menjaga kelestarian lingkungan, menjaga kesehatan diri dan kesehatan lingkungannya. Pelatihan petani dilakukan secara berkelanjutan, sehingga petani paham tentang hakekat pertanian organik yang sebenarnya bukan hanya tidak menggunakan bahan-bahan kimia.

\section{Pembelian dan Pengolahan Pasca Panen}

Pembelian dilakukan oleh petugas ICS bidang pembelian dengan mengikuti prosedur pembelian yang telah ditetapkan. Setiap pembelian harus dengan data yang jelas tentang asal usul gabah dan status petani. Setiap penjualan oleh petani harus dibandingkan dengan data perkiraan hasil panen petani penjual dan harus mengisi formulir pembelian. Gabah yang dibeli dimasukkan ke dalam karung yang disediakan oleh ICS dan harus dilabel sesuai dengan asal usul gabah dan status keorganikannya. Pemeriksaan terhadap mutu gabah dilakukan untuk menentukan grade. Harga jual didasarkan kepada mutu gabah sesuai dengan grade yang dipenuhinya, dan harga tersebut sudah disepakati oleh ICS dan petani sebelumnya.

Gabah hasil pembelian disimpan dan pengolahan lebih lanjut oleh petugas ICS. Penyimpanan dilakukan digudang yang mampu menjamin tidak terjadinya kontaminasi. Gabah dipisahkan berdasarkan status keorganikannya dengan memberi sekat diantara gabah organik, konversi dan non organik. Gabah organik harus diolah dengan cara-cara organik, termasuk dalam penjemuran dan penggilingan. Penggilingan untuk padi organik dilakukan di mesin giling yang khusus untuk gabah organik. Hasil akhirnya dikemas dalam kemasan plastik yang divakum dan yang tidak divakum.

Status keorganikan suatu produk akan dapat hilang apabila mengalami salah satu tahap yang tidak sesuai dengan prinsip-prinsip organik. Untuk itu gapoktan membuat aturan yang baku untuk proses distribusi. Produk organik harus diangkut ke pembeli dengan kendaraan yang terpisah dari produk non organik.

\section{Inspeksi dan Sertifikasi Eksternal}

Inspeksi internal dilakukan oleh inspektur internal kepada semua petani anggota. Inspeksi ini dilakukan sebelum inspeksi eksternal oleh lembaga sertifikasi organik dilakukan. Pengelola ICS membuat dan menyepakati jadwal inspeksi dengan lembaga sertifikasi organik. Pengelolah ICS dibantu inspektur internal melakukan sosialisasi kepada petani tentang inspeksi internal. Pelaksanaan inspeksi eksternal oleh lembaga sertifikasi didampingi oleh koordinator ICS. Hasil penilaian lembaga sertifikasi akan dibandingkan dengan hasil inspeksi internal yang dilakukan oleh inspektur internal. Hasil tersebut menjadi dasar bagi lembaga sertifikasi untuk mengambil keputusan tentang status keorganikan suatu lahan.

\section{Analisis Persepsi terhadap Penerapan ICS}

Analisis ini bertujuan untuk melihat persepsi anggota terhadap penerapan ICS. Hasil analisis biplot pada penelitian persepsi anggota poktan bersertifikat dapat memberikan total keragaman 57,4\%. Sumbu utama pertama memberikan kontribusi 39,0\% dari keragaman yang dapat diterangkan, dan sumbu utama kedua memberi kontribusi $18,4 \%$. 
Dari gambar biplot kelompok bersertifikat yang tersaji dalam Gambar 1, menunjukkan bahwa sebagian besar petani terletak disekitar vektor yang terbentuk dari semua peubah mulai dari X1 sampai X9. Secara umum dapat dikatakan bahwa sebagian besar petani memberikan nilai yang cukup baik untuk semua peubah yang ada. Hanya beberapa petani yang menjauh dari vektor yaitu petani ke-3, ke-9, ke-19, ke-5, ke-13, dan ke24. Petani yang memberikan penilaian yang kurang baik tersebut, sebagian besar berasal dari kelompok Srilangen 2 dan hanya anggota kelompok ke-24 yang berasal dari kelompok Mekarjaya. Hal ini menunjukkan bahwa anggota kelompok Mekarjaya mempunyai persepsi yang lebih baik dari kelompok Srilangen2. Bagi kedua kelompok hal tersebut perlu diantisipasi, terutama bagi kelompok Srilangen 2, karena dalam sertifikasi dengan pola ICS kekompakan anggota sangat memengaruhi berhasil tidaknya memperoleh sertifikat organik atau mempertahankan status sertifikat organik.

Keragaman persepsi anggota poktan bersertifikat terhadap suatu peubah dapat dilihat dari panjang vektor yang terbentuk. Semakin panjang garis vektor berarti persepsi responden terhadap peubah tersebut beragam, dan semakin pendek berarti cukup seragam. Dari gambar biplot, dapat dilihat bahwa panjang vektor yang terbentuk dari semua peubah tidak sama, dapat dikatakan bahwa responden memberikan persepsi yang berbeda untuk masing-masing peubah. Garis vektor terpanjang terbentuk dari persepsi terhadap pembelian, penanganan, pengolahan dan ekspor $\left(\mathrm{X}_{8}\right)$, yang berarti anggota poktan mempunyai persepsi yang paling beragam terhadap peubah ini. Petani yang satu dengan petani yang lain memberikan penilaian relatif tidak sama terhadap prosedur pembelian yang dilakukan Gapoktan, harga yang diberikan, penanganan pasca panen dan mitra kerja yang dilakukan Gapoktan. Dengan demikian, peubah pembelian, penanganan, pengolahan dan ekspor $\left(\mathrm{X}_{8}\right)$ perlu diperhatikan oleh pengurus kelompok dan Gapoktan/ICS, agar perbedaan persepsi tersebut bisa dikurang.

Persepsi petani yang paling seragam terbentuk dari penilaian terhadap personel organisasi dan ICS (X6). Hal ini terlihat dari panjang vektor yang terbentuk paling pendek dibandingkan panjang vektor dari peubah lainnya, berarti petani mempunyai penilaian hampir sama terhadap orang-orang yang duduk sebagai petugas inspektor internal, petugas pendamping maupun pengurus Gapoktan yang dinilai dari kinerja dan jumlah personel yang tersedia.

Di lihat dari hubungan antar peubah, persepsi terhadap uraian struktur dan kegiatan kelompok $\left(\mathrm{X}_{2}\right)$ lebih erat hubungannya dengan persepsi terhadap pelatihan $\left(\mathrm{X}_{7}\right)$ artinya korelasi antara keduanya lebih tinggi dibandingkan dengan peubah lainnya. Hal ini dapat dilihat dari sudut yang terbentuk antar keduanya yang sangat kecil dibanding dengan sudut lainnya.

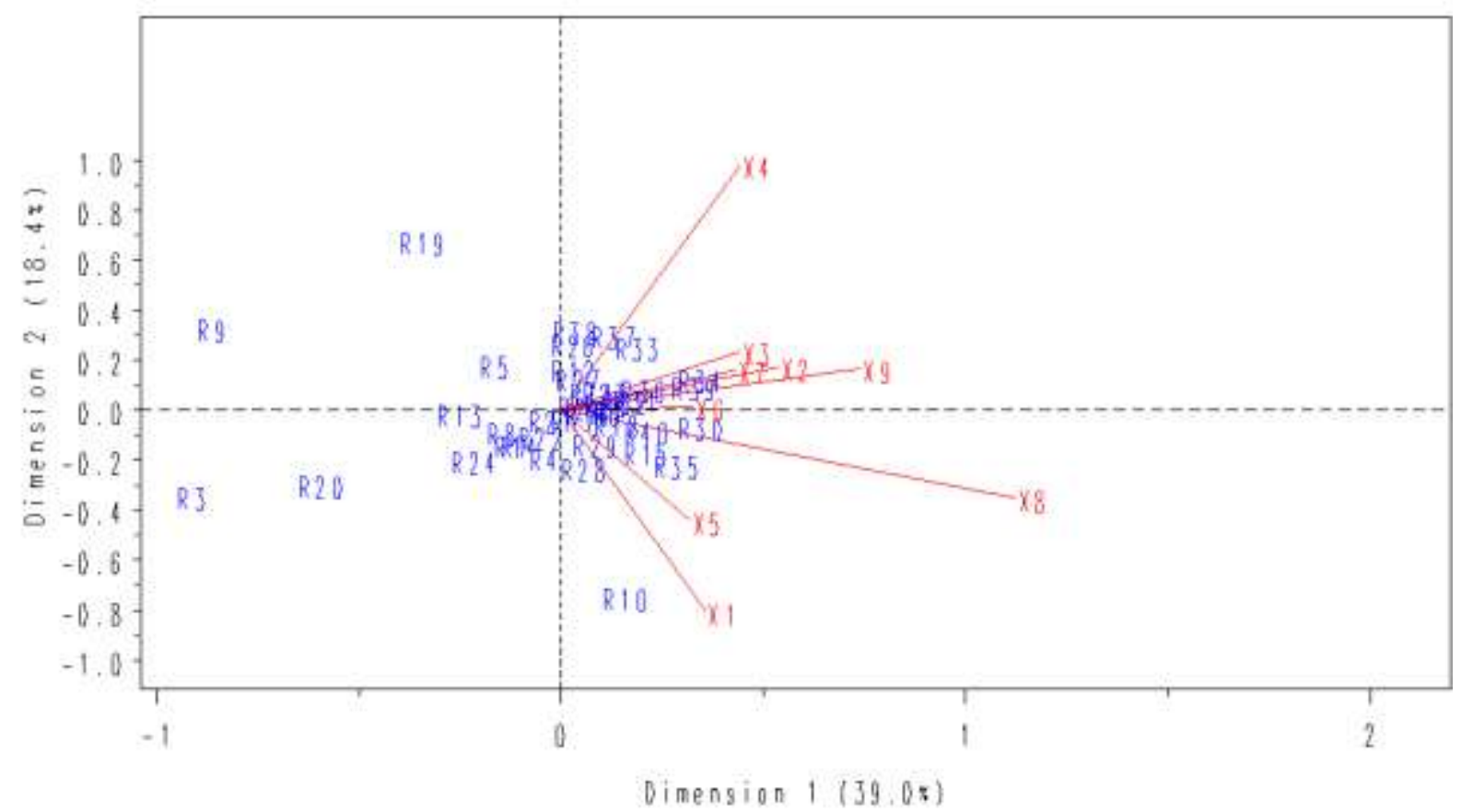

Gambar 1. Hasil biplot untuk poktan bersertifikat organik 
Makna yang terkandung dari hasil analisis ini adalah pemahaman anggota terhadap hak dan kewajibannya dalam organisasi dan kepuasan anggota terhadap struktur dan kegiatan yang dilakukan kelompok erat hubungannya dengan kepuasan terhadap pelatihan-pelatihan yang telah dilakukan. Keeratan hubungan yang paling lemah adalah antara mengelola kemutakhiran dan pendistribusian panduan ICS $\left(\mathrm{X}_{1}\right)$ dan standar organik internal $\left(X_{4}\right)$, karena sudut yang terbentuk diantara kedua peubah tersebut sangat besar. Maknanya adalah pemahaman dan kepuasan anggota terhadap tatacara distribusi dokumen ICS tidak ada hubungan yang erat dengan pemahaman anggota dengan standar organik internal.

Hasil analisis biplot terhadap persepsi anggota poktan yang tidak bersertifikat dapat dilihat dalam Gambar 2. Analisis ini mampu memberikan total keragaman $66,2 \%$. Sumbu utama pertama memberikan kontribusi $48,7 \%$ dari keragaman yang dapat diterangkan dan sumbu utama kedua memberi kontribusi 17,5\%.

Berdasarkan hasil analisis biplot, terlihat bahwa sebagian besar petani di poktan tidak bersertifikat organik berjauhan dari garis vektor yang terbentuk. Hal ini berarti bahwa banyak dari petani pada poktan tidak bersertifikat organik merasa belum puas/belum paham tentang peubah yang ditanyakan. Petani dari poktan Sribangkit 2 yaitu petani R21 sampai R40, cenderung mempunyai persepsi sama, karena terlihat saling berdekatan satu sama lain, sedangkan petani dari poktan Srilangen 1 (petani 1 sampai 20) mempunyai persepsi lebih bervariasi karena cenderung berjauhan satu sama lain. Dari vektor yang terbentuk, hanya peubah pengawasan lahan dan prosedur persetujuan $\left(X_{5}\right)$ dan peubah pembelian, penanganan, pengolahan dan ekspor $\left(\mathrm{X}_{8}\right)$ yang paling banyak didekati oleh petani, sehingga dapat dikatakan secara umum bahwa petani memiliki persepsi cukup baik terhadap kedua peubah ini dibandingkan peubah lainnya. Penilaian baik ini terutama berasal dari petani poktan Sribangkit 2, sedangkan beberapa petani dari poktan Srilangen 1 justru menjauh dari kedua peubah ini. Hal ini memberi gambaran bahwa petani kelompok Srilangen 1 yang belum puas/belum paham terhadap pengawasan lahan dan prosedur persetujuan $\left(X_{5}\right)$ dan prosedur pembelian, penanganan, pengolahan dan ekspor $\left(\mathrm{X}_{8}\right)$ yang dilaksanakan ICS.

Peubah-peubah yang banyak dijauhi oleh petani antara lain pengelolaan, kemutahiran dan pendistribusian panduan ICS $\left(\mathrm{X}_{1}\right)$, uraian struktur dan kegiatan kelompok $\left(\mathrm{X}_{2}\right)$, manajemen risiko $\left(\mathrm{X}_{3}\right)$, standar organik internal $\left(\mathrm{X}_{4}\right)$, personel organisasi dan ICS $\left(X_{6}\right)$, pelatihan $\left(X_{7}\right)$, inspeksi dan sertifikasi eksternal $\left(X_{9}\right)$. Banyaknya peubah yang dijauhi petani membuktikan bahwa pemahaman dan kepuasan anggota kedua poktan tidak bersertifikat ini masih kurang sehingga wajar jika belum dapat memperoleh sertifikat organik. Untuk itu, agar Gapoktan Simpatik

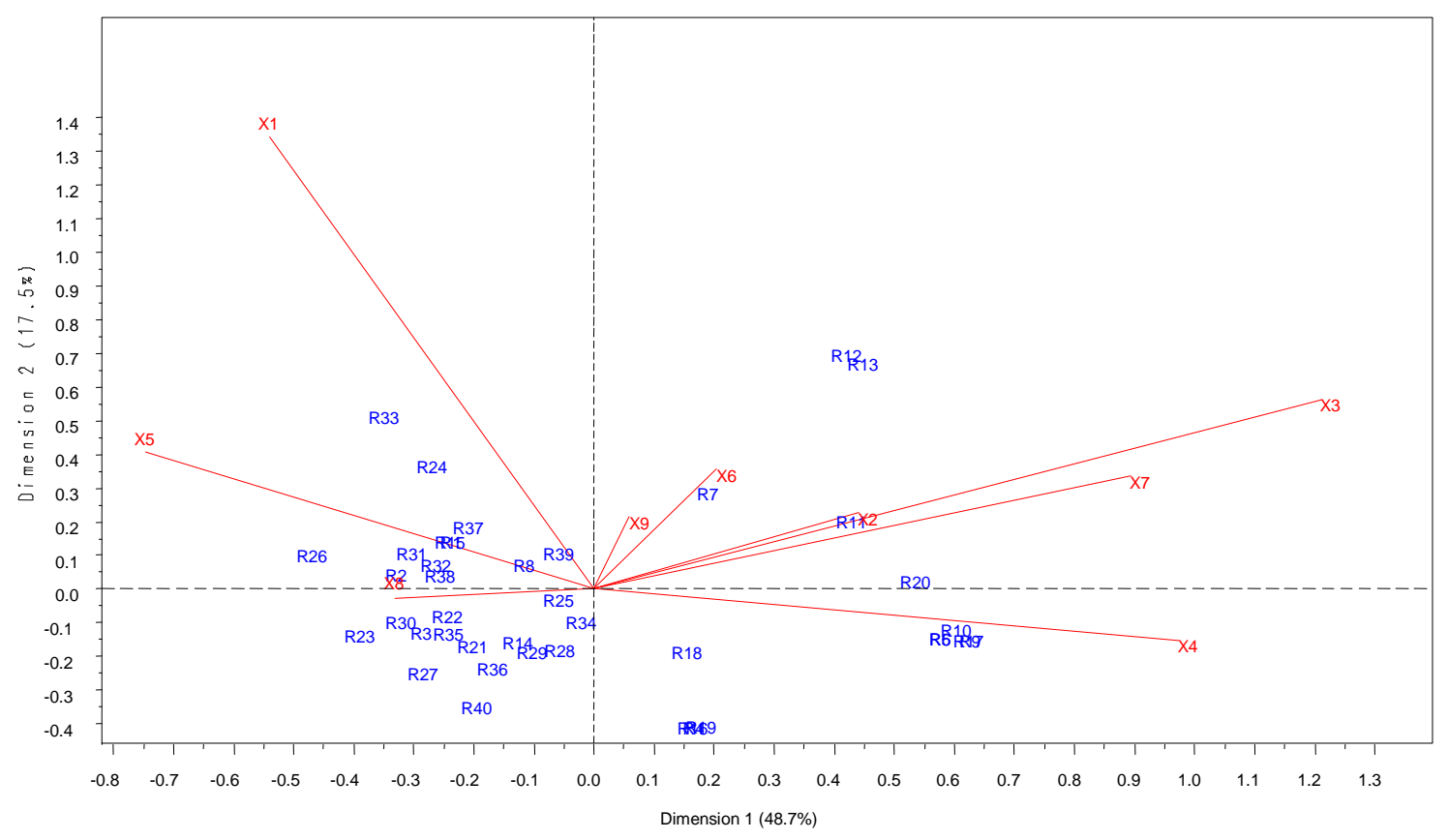

Gambar 2. Hasil biplot untuk poktan tidak bersertifikat organik 
berhasil menjadikan kedua poktan ini menjadi kelompok bersertifikat organik maka tujuh peubah yang dijauhi tersebut harus mendapat perhatian serius untuk dibina, sehingga pemahaman dan kepuasan anggota dapat ditingkatkan.

Keragaman persepsi petani terhadap masing-masing peubah dapat dilihat dari panjang pendeknya vektor yang dihasilkan. Berdasarkan biplot pada poktan tidak bersertifikat organik, terlihat bahwa garis vektor terpanjang terbentuk dari peubah manajemen risiko $\left(\mathrm{X}_{3}\right)$, sedangkan garis vektor terpendek terbentuk dari peubah inspeksi dan sertifikasi eksternal ICS $\left(X_{9}\right)$. Maknanya adalah poktan cenderung memiliki pemahaman yang berbeda terhadap manajemen risiko $\left(\mathrm{X}_{3}\right)$, padahal dalam sertifikasi organik pemahaman terhadap peubah ini sangat penting, agar petani paham potensi-potensi bahaya yang dapat timbul yang akan memengaruhi keorganikan produk yang dihasilkannya. Vektor terpendek yang terbentuk dari peubah inspeksi dan sertifikasi eksternal ICS ( $\left.\mathrm{X}_{9}\right)$ memberi gambaran bahwa sebagian besar poktan punya pemahaman yang sama terhadap peubah ini.

Di lihat dari hubungan antar peubah dalam biplot, kelompok tidak bersertifikat organik ini, peubah uraian struktur dan kegiatan kelompok $\left(\mathrm{X}_{2}\right)$ lebih erat hubungannya dengan peubah manajemen risiko $\left(X_{3}\right)$ yang ditunjukkan dengan sudut yang paling kecil dibandingkan dengan sudut lainnya yang terbentuk. Hal ini berarti bahwa ada hubungan yang cukup erat antara pemahaman dan kepuasan anggota terhadap uraian struktur dan kegiatan kelompok ( $\left.\mathrm{X}_{2}\right)$ dengan pemahaman anggota terhadap manajemen risiko $\left(X_{3}\right)$. Keeratan hubungan yang paling lemah adalah peubah standar organik internal $\left(\mathrm{X}_{4}\right)$ dan peubah pengawasan lahan dan prosedur persetujuan $\left(X_{5}\right)$, karena sudut yang terbentuk sangat besar. Keeratan hubungan yang cukup lemah juga terlihat antara peubah standar organik internal $\left(X_{4}\right)$ dengan peubah pembelian, penanganan, pengolahan dan ekspor $\left(\mathrm{X}_{8}\right)$, peubah manajemen risiko $\left(X_{3}\right)$ dengan peubah pembelian, penanganan, pengolahan dan ekspor $\left(\mathrm{X}_{8}\right)$, peubah standar organik internal $\left(X_{4}\right)$ dengan peubah pengawasan lahan dan prosedur persetujuan $\left(\mathrm{X}_{5}\right)$.

Analisis biplot antara kelompok yang bersertifikat dan tidak bersertifikat memberikan gambaran bahwa persepsi poktan yang bersertifikat berbeda dengan kelompok yang tidak bersertifikat. Pemahaman kelompok yang bersertifikat terhadap berbagai peubah jauh lebih baik dari kelompok tidak bersertifikat. Hal ini mungkin salah satu faktor yang menyebabkan kelompok bersertifikat dapat memperoleh sertifikat organik. Pemahaman yang baik terhadap pedoman penerapan ICS yang telah ditetapkan Gapoktan sangat diperlukan agar petani tahu, lalu memahami dan mau menerapkan prinsip-prinsip pertanian organik.

Hasil analisis biplot terhadap kelompok bersertifikat maupun tidak bersertifikat menunjukkan bahwa ada ketidakpuasan dan ketidakpahaman dapat menjadi peluang yang menyebabkan berpindah dari pertanian organik menjadi pertanian konvensional. Berdasarkan penelitian Setiawan (2009) terhadap petani padi organik di Jawa Barat, beberapa kabupaten mengalami pelambatan dan penurunan pengembangan pertanian organik, yang salah satunya disebabkan oleh ketidakkonsistenan petani dalam bertani organik. Hasil penelitian Yunasaf (2005) memperlihatkan bahwa adanya hubungan yang kuat antara kepemimpin dan keefektifan kelompok, sehingga peran ketua dan jajarannya sangat penting untuk dapat merangkul anggotanya mencapai tujuan organisasi yang telah ditetapkan.

Pemahaman petani terhadap persyaratan yang masih kurang memerlukan sosialisasi dan bimbingan yang lebih baik dan kontinu. Peran pemerintah sangat diharapkan, karena berdasarkan penelitian yang ada, secara kelembagaan pengembangan padi organik belum mendapat dukungan dan komitmen penuh dan konsisten dari pelaku kebijakan, baik di pusat maupun di daerah (kabupaten/kota) (Setiawan, 2009). Apalagi saat ini, Gapoktan masih tergantung kepada traider yang menyebabkan Gapoktan kurang memiliki posisi tawar yang dapat diandalkan anggota untuk meningkatkan kesejahteraannya. Peran pemerintah dalam kondisi seperti ini sangat diperlukan untuk membantu Gapoktan dalam menfasilitasi poktan yang benar-benar berminat untuk disertifikasi, sehingga Gapoktan dapat lebih mandiri dan leluasa dalam mengambil kebijakan untuk kepentingan anggotanya.

\section{KESIMPULAN}

Kedua usahatani padi organik bersertifikat dan tidak bersetifikat merupakan usahatani yang layak untuk diusahakan, karena mempunyai nilai $\mathrm{R} / \mathrm{C}$ ratio lebih dari 1, yaitu 1,77 (pendapatan lebih tinggi) untuk bersertifikat dan 1,53 untuk tidak bersertifikat (pendapatan lebih rendah). Secara umum persepsi anggota poktan bersertifikat 
terhadap panduan umum penerapan ICS lebih baik dari kelompok tidak bersertifikat organik. Dalam beberapa petani dari poktan bersertifikat mempunyai tingkat kepuasan dan pemahaman masih kurang terhadap prosedur tentang pembelian, penanganan, pengolahan dan ekspor yang dilakukan IC, serta di sisi lain petani poktan tidak bersertifikat hampir sebagian besar belum puas dan belum paham terhadap penerapan ICS.

\section{DAFTAR PUSTAKA}

[AOI]. Aliansi Organik Indonesia. 2009. Statistik Pertanian Organik Indonesia 2009. AOI, Bogor.

Gapoktan Simpatik. 2011. Gambaran Umum ICS Gapoktan Simpatik. Tasikmalaya.

Lechleitner, F and Eisenlohr, U. 2004. Revised IFOAM Producer Manual for Setting Up and Harmonizing an Internal Control System (ICS). Institute for Market Ecology (IMO), Swiss.
Pascal, L, 2007. Peraturan, Standar dan Sertifikasi untuk Ekspor Produk Pertanian terjemahan oleh Rivai Suparta dan Astari Mitra, 2007. FAO Project OSRO/INS/604/USA2007

Setiawan, I, 2009. Membudayakan Padi Organik. http://www.ahmadheryawan.com/ opinimedia/ekonomi-bisnis/6678 - membudayakan - padi - organik.html. [10 Januari 2011]

Syam, M. 2008. Padi Organik dan Tuntutan Peningkatan Produksi Beras. Jurnal Iptek Tanaman Pangan, 3(1)..

Wirosoehardjo, K. 1981. Dasar-Dasar Demografi. Lembaga Demografi Fakultas Ekonomi. Universitas Indonesia. Jakarta

Yunasaf, U, 2005. Kepemimpinan Ketua Kelompok dan Hubungan dengan Keeefektifan Kelompok. Universitas Padjajaran, Bandung. 